\title{
A MÉM NAK genetikus talajtérkép bemutatása és talajosztályozási kategóriáinak elemzése
}

\author{
${ }^{1}$ KOCSIS Mihály, ${ }^{2}$ BERÉNYI ÜVEGES Judit, ${ }^{3}$ VÁRSZEGI Gábor és \\ ${ }^{1}$ SISÁK István
}

${ }^{1}$ Pannon Egyetem Georgikon Kar Növénytermesztéstani és Talajtani Tanszék, Keszthely; ${ }^{2}$ NÉBIH, Növény-, Talaj- és Agrárkörnyezet-védelmi Igazgatóság Talajvédelmi Hatósági Osztály, Budapest; ${ }^{3}$ NÉBIH, Növény-, Talaj- és Agrárkörnyezet-védelmi Igazgatóság Agrárkörnyezet-védelmi és Koordinációs Osztály, Budapest

\section{Bevezetés}

Magyarország talajairól nagyon sok pontszerü és térképi információ áll rendelkezésre, de a hazai talajtan nagy adóssága, hogy ezek csak részben lettek digitalizálva és nem értékelték még komplex módon (SISÁK \& BÁMER, 2008), holott a digitális talajtérképezési eljárások erre lehetőséget nyújtanának, és a hazai talajvédelmi stratégia (NÉMETH et al., 2005), valamint az EU INSPIRE direktívája (EC, 2007) is elöirányozza.

Munkánkban célul tüztük ki, hogy egy szélesebb körben kevéssé ismert talajtérképet, valamint annak előzményeit jelentő térképezési munkákat bemutassuk. A hazai talajtérképezés történetét és helyzetét legutóbb VÁRALLYAY (2012) foglalta össze. Részben az ő munkájára támaszkodva, de további, általa nem tárgyalt információkat is felhasználva mutatjuk be Magyarország MÉM NAK (Mezőgazdasági és Élelmezésügyi Minisztérium Növényvédelmi és Agrokémiai Központ) Genetikus Talajtérképet és előzményeit, valamint az összehasonlításához felhasznált térképeket.

A MÉM NAK talajtérképet (JENEY \& JASSÓ, 1983) az üzemi genetikus talajtérképek, a Géczy-féle talajismereti térképek, valamint szakértői becslések információi alapján szerkesztették. A munkát a MÉM NAK szakmai koordinálásával, valamint ezen intézmény megyei állomásain dolgozó talajtani szakembereinek segítségével készítették el 1:200.000 méretarányban (MARKÓ, 2014; szóbeli közlés).

GÉCZY (1959) doktori értekezésében fogalmazta meg egy újabb talajtérképezés alapelveit, amely eredményeinek hasznosítására a talajhasználat és talajminősítés területén későbbi publikációiban tett javaslatokat (1960, 1962, 1964), majd könyv formájában összegezte az időközben ténylegesen megvalósult országos jelentőségü talajtérképezési munka eredményeit (GÉCZY, 1968). Az 1:25.000 léptékü talajismereti térképek 1958-1961 között készültek, községhatáros térképlapokon.

Postai cím: KOCSIS MIHÁLY, PE Georgikon Kar, Növénytermesztéstani és Talajtani Tanszék, 8360 Keszthely, Deák Ferenc utca 16. E-mail: kocsis.mihaly@2010.georgikon.hu 
A térképezés során a feltárt és leírt talajszelvény pontok helyét, valamint az azokat magukba foglaló talajfoltokat rögzítették. Az lehatárolt foltoknak csak egy része tartalmaz talajtani adatokat (talaj fötípus, fizikai féleség, kövesség, erodáltság), a többi a felszínborítást jelzi (erdő, vízfelszín). A talajszelvényekről csak a helyszíni leírás adatai állnak rendelkezésre, azok is nehezen feldolgozható formában (SISÁK \& BÁMER, 2008).

A Géczy talajismereti térképek - úgy, mint a KREYBIG-féle talajtérképek (KREYBIG, 1937) - léptéke legtöbb esetben csak névleges, mert 1:25.000 méretarányú topográfiai alapra készültek, de a térképek tényleges térbeli felbontása a megszokottnál lényegesen rosszabb (TóTH \& MÁTÉ, 2006), emiatt ezek csupán regionális növénytermesztés tervezéséhez használhatóak (Kocsis et al., 2014b).

Hazánkban az 1960-as évekre kialakított nagyüzemi gazdálkodás - téeszesítés -, valamint a mütrágyázási- és agrotechnikai eljárások fejlődése indukálta, hogy a méréseken alapuló mind több talajinformációt tartalmazó, egyre nagyobb felbontású és tematikusan egyre specifikusabbá váló talajtérképek készüljenek (SzABOLCS et al., 1966; VÁRALLYAY, 1989). Az 1960-as évek elején kezdödött el hazánkban a mezőgazdasági nagyüzemek területeire kiterjedő 1:10.000 méretarányú üzemi genetikus talajtérképek felvételezése, amelyek az Országos Mezőgazdasági Minősítő Intézet (OMMI) kiadásában jelentek meg. Az intézmény később a NÉBIH rendszerébe tagozódott be. A térképezés során a szántóföldekröl környezeti- és domborzati viszonyoktól függöen 10-12 hektáronként talajszelvényeket tártak fel. A helyszíni leírások, s begyűjtött talajminták laboratóriumi vizsgálatai alapján szerkesztették meg a talajtérképeket, valamint a hozzájuk tartozó tematikus leíró és tanácsadó kartogramokat. Becslések szerint az 1980-as évek közepére hazánk mezőgazdasági területének mintegy 53-55\%-ára készült el a nagyméretarányú genetikus talajtérképezés, 1991-re a föltérképezett területek aránya elérte a 64\%-ot (SZABÓNÉ KELE, 1999).

1955-ben a Kreybig-féle átnézetes talajismereti térképezésből származó információk szintéziséből STEFANOVITS és SzÜCS (1961) elkészítette 1:200.000 méretarányban az ország áttekintő genetikus talajtérképét, majd az évtized második felében beinduló a térképezési munka helyszíni felvételezéseire, valamint talajvizsgálati adatokra alapozva 1960-ban megszerkesztették 1:500.000 léptékben is (StEFAnOvits, 1963; VÁrallyay, 2012). Ez utóbbi már kis eltérésekkel azt a talajosztályozási rendszert használta, ami ma is érvényben van.

Az 1961-ben az OMMI által kiadott Magyarország genetikus talajtérképe 29 különböző talajféleséget ábrázol, amelyek 6 típusra és 23 altípusra oszlanak meg. A térképen a talajtípusok- és altípusok hét fizikai féleséget (homokos, homokos vályog, középkötött vályog, agyag és agyagos vályog, nyirok, szerves) különböztetnek meg, amelyeket talajképző kőzettípusonként (löszös; harmadkori és idősebb üledék; glaciális és tavi, vagy alluviális) csoportosítva ábrázoltak. A szerzők külön kategóriaként jelenítették meg a kavicsos üledéken és a vörös mállási rétegen képzödött talajokat. A tömör kőzeteket eredetük szerint öt csoportban jelölik (homokkő; agyagpala és fillit; mészkő és dolomit; gránit és porfirit; andezit, riolit és bazalt). 
Az 1970-es években az „ország agroökológiai potenciáljának felmérése” címü kutatómunka keretében 1:100.000 léptékben elkészítették a „Magyarország termöhelyi adottságait meghatározó talajtani tényezök" című térképet, amely az egyik legjelentősebb országos talajtérképezési munka és sokáig az egyedüli digitális adatállomány volt (VÁRALLYAY et al, 1979; 1980). Az Agrotopográfiai térképek - röviden AGROTOPO - néven 1:100.000 méretarányú topográfiai térképlapokon nyomtatásra került (MÉM, 1983-1988), majd a 2000-es évek elejére egy térinformatikai adatbázist is létrehoztak ezek alapján (MTA ATK TAKI, 2013). Az AGROTOPO térképek eredetileg a „talajtípusról és altípusról; talajképző közetröl; a talaj kémhatásról és mészállapotról; fizikai talajféleségröl; a talaj vízgazdálkodási tulajdonságairól; a talaj szervesanyag-készletéröl; termöréteg vastagságáról" szolgáltattak lényeges talajinformációkat, amelyek majd a talaj „agyagásványtársulásaira" (STEFANOVITS \& DOMBÓVÁRINÉ FEKETE, 1985; STEFANOVITS, 1989; DOMBÓVÁRINÉ FEKETE \& STEFANOVITS, 1996) és a „talaj-értékszámra” vonatkozó adatokkal lettek kiegészítve (VÁRALLYAY, 2012). A 1:100.000 névleges méretarányú térképlapokon 31 talajosztályozási egység különíthető el, amelyek közt vegyesen összevonva talaj fötípus, talajtípus, altípus és változatok is szerepelnek (SISÁK \& BENÖ, 2012), tehát a talajtani változatosságnak csak a töredékét reprezentálják. A munkának azonban nem is ez volt a célja, hanem a mezőgazdasági célú természettudományos kutatások részeként az agroökológiai körzetek tájtermesztési potenciáljának a megalapozása (LÁNG, 1983).

Munkánk során a térkép információtartalmának számbavétele és rendszerezése mellett két kiemelt terület, egy földrajzi nagytáj és egy középtáj esetében vizsgáltuk azt is, hogy a Shuttle Radar Topograpgy Mission (SRTM) domborzati modellböl levezetett adatok és a talajtípusok között milyen kapcsolat van, és az AGROTOPO adatbázissal hasonlítottuk össze. Az AGROTOPO térbeli felbontását tekintve hozzávetőlegesen megegyezik a MÉM NAK talajtérképpel, továbbá digitális formában is rendelkezésre állt, ezért az értékelésben elsősorban ezzel a térképpel vetettük össze a bemutatásra szánt térképet. Az értékelésben elsősorban a talajgenetikai információkat elemeztük. A korábbi (STEFANOVITS \& SzÜCS, 1961) genetikus talajtérképről csak összefoglaló információkat használtuk fel az összevetésben.

\section{Vizsgálati anyag és módszer}

A vektoros állomány alapjául szolgáló, Magyarország Genetikus Talajtérképe címü papír alapú térkép 1983-ban a volt Mezőgazdasági és Élelmezésügyi Minisztérium Növényvédelmi és Agrokémiai Központjának (MÉM NAK) szakmai koordinálásával, valamint MÉM NAK megyei állomásainak bevonásával készült el 1:200.000 méretarányban. Az országos talajtérképet a rendelkezésre álló 1:10.000 üzemi genetikus és 1:25.000 Géczy-féle talajismereti térképezés, valamint szakértői becslések információi alapján országrészenként (kb. 3-4 megyénként) szerkesztették meg, majd a térképlapokat országossá rajzolták össze (JENEY \& JASSÓ, 1983).

A talajtérkép térinformatikai (digitális) feldolgozását a 2000-es évek végén a megyei növény- és talajvédelmi szolgálatok térinformatikusai végezték a Növény- 
és Talajvédelmi Központi Szolgálat koordinálásával. A térkép szerkesztéséröl ennél több részlet nem ismert, azt ugyanis nem publikálták, és a munkát végző szakemberek sem voltak számunkra elérhetőek.

Munkánk során a vektorizált térképi állományból indultunk ki, azt korrigáltuk, finomítottuk, illetve attribútum tábláját kiegészítettük a raszteres georefereált (vetületbe illesztett) térkép alapján. A térinformatikai műveleteket az ESRI ArcGIS 10.0 szoftver segítségével végeztük el.

A MÉM NAK talajtérképe az első olyan egységesen szerkesztett országos térképi állomány, amely nagy részben tartalmazza a hazai genetikus talajosztályozás rendszertani egységeit (típus és altípus), a talajok fizikai féleségéröl és a talajképző kőzetekről is áttekintő tájékoztatást ad. A térkép a talajinformációkat a SzABOLCS és munkatársai (1966) által kiadott „A genetikus üzemi talajtérképezés módszerta$n a$ " címü könyvben ismertetett nomenklatúra alapján tünteti fel. Átfordítottuk a nagyméretarányú talajtérképezéshez kiadott Útmutató (JASSÓ et al., 1989) szerinti talajtérképi kódokat is.

Az interpretációhoz felhasználtuk a Shuttle Radar Topograpgy Mission (SRTM) müholdas felvételezés során Magyarország területére elkészített digitális domborzati modellt (kb. 90x90 m pixelméret), amelyet a NASA (National Aeronautic and Space Administration) még 1996-ban azzal a céllal kezdett el kialakítani, hogy a Föld felszínének mintegy 80\%-ról részletes domborzati információkat gyüjtsön (TIMÁr et al., 2003).

A digitális térképet felosztottuk Magyarország kistáj kataszterének (MAROSI \& SOMOGYI, 1990; DÖVÉNYI, 2010) 1:1.000.000 léptékü földrajzi tájbeosztása szerint. Térinformatikai eszközökkel kiszámítottuk középtájanként a térképi foltok területi részarányát és az SRTM modellből a tengerszint feletti magasság átlagát. A régebbi és újabb kistáj kataszter nem képezte az értékelö összehasonlítás alapját, mert abban kistájanként tárgyalják a szerzők - sok más mellett - a talajföldrajzi viszonyokat.

\section{Vizsgálati eredmények értékelése és megvitatása}

A MÉM NAK genetikus talajtérkép vektoros állományában lévő 5214 poligonból 3333 darab rendelkezik talajinformációval, tehát 1881 térképi folt nem mezögazdasági célú területhasználatot jelöl. A térkép az ország területének 84,1\%-án mutat talajtani kategóriákat (talajtípus és altípus) a maradék 15,9\% területen felszínborítási információkat közöl. A nem talajtani kategóriák döntően erdők $(13,6 \%)$, ezt követik a lakott területek és a vízfelületek (mindkettő 1,1\%) és a vízjárta területek (0,1\%). Ez utóbbi csak két középtájban (Alpokalja, Győri-medence), egy-egy folton fordul elö. A lakott területek aránya csak olyan tájakban jelentős, ahol nagyvárosok vannak. Ez a kategória 3\% fölött van négy középtájban (Dunamenti-síkság, Dunazug-hegyvidék, Hajdúság és Alsó-Tiszavidék), és 1-3\% az aránya nyolc további középtájban. A vízfelületek jellemzően igen kis területen találhatók, arányuk egy százalék alatti, több esetben pedig teljesen hiányoznak. 
Ez alól csak két kivétel van. A Balaton-medence területének csaknem 42\%-a a tó maga, a Közép-Tiszavidéknek pedig több mint 3\%-a a Tisza-tó.

A talaj fötípusok (MÉM, 1982; JASSÓ et al., 1989) mindegyike megjelenik a térképen; legnagyobb arányban a barna erdőtalajok $(23,19 \%)$, a csernozjomok $(19,51 \%)$ és a réti talajok $(20,64 \%)$, melyek együttesen a termöterület több mint felét, 63,34\%-át fedik le (1. táblázat).

1. táblázat

Az országos léptékü talajtérképeken szereplő talaj főtípusok területi megoszlásai

\begin{tabular}{|c|l|c|c|c|}
\hline \multirow{2}{*}{ Kód } & \multicolumn{1}{|c|}{$\begin{array}{c}\text { (2) } \\
\text { Talaj fótípus }\end{array}$} & $\begin{array}{c}\text { (3) } \\
\text { Magyarország } \\
\text { genetikus } \\
\text { talajképe } \\
(1960)\end{array}$ & $\begin{array}{c}\text { (4) } \\
\text { AGROTOPO } \\
\text { Adatbázis } \\
(1980)\end{array}$ & $\begin{array}{c}\text { MÉM NAK } \\
\text { genetikus talaj- } \\
\text { térkép } \\
(1983)\end{array}$ \\
\cline { 3 - 5 } & \multicolumn{3}{|c|}{ Területi arány, \% } \\
\hline I. & Váztalajok & 6,68 & 7,98 & 8,26 \\
II. & Közethatású talajok & 2,25 & 1,25 & 0,39 \\
III. & Barna erdőtalajok & 36,10 & 30,60 & 23,19 \\
IV. & Csernozjom talajok & 20,66 & 24,92 & 19,51 \\
V. & Szikes talajok & 6,12 & 6,95 & 3,89 \\
VI. & Réti talajok & 19,94 & 23,88 & 20,64 \\
VII. & Láptalajok & 1,74 & 1,47 & 1,24 \\
VIII. & Mocsári erdőtalajok & 0,32 & 0,10 & 0,04 \\
IX. & Öntés- és lejtőhorda- & 5,03 & 2,85 & 6,90 \\
\hline
\end{tabular}

Az 1. táblázatban szereplő adatokat értékelve elmondható, hogy a három országos talajtérkép közül az Stefanovits-Szücs-féle genetikus talajtérképen szerepelnek legkisebb területen (6,68\%) a váztalajok. Az említett talaj fótípust az AGROTOPO adatbázis és a MÉM NAK genetikus talajtérkép - néhány tizednyi eltéréssel - közel azonos területi arányban tartalmazza. Barna erdőtalajinkról területi összevetésben a legtöbb (36,10\%) információval az 1960-as talajtérkép szolgál. A három közül az AGROTOPO adatbázisban legnagyobb a csernozjomok (24,92\%), a szikesek $(6,95 \%)$ és a réti $(23,88 \%)$ talajok területi részaránya. A Stefanovits és Szücs által szerkesztett félmilliós léptékủ - 1:500.000 méretarányú -, országos genetikus talajtérkép lényegesen rosszabb térbeli felbontású, mint az AGROTOPO adatbázisé (1:100.000) vagy a MÉM NAK genetikus talajtérképé (1:200.000). A talajtérképen a talajfoltokon kívül csak két felszínborítási kategória - nagyobb állóvizek és városok - van feltüntetve, amelyek területi aránya eléri az 1,17\%-ot. A MÉM NAK genetikus talajtérképpel ellentétben - az AGROTOPO adatbázissal megegyezően nem tüntet fel erdő és a vízjárta terület kategóriákat.

A MÉM NAK genetikus talajtérkép jelenleg érvényben lévő hazai talajosztályozási rendszer (MÉM, 1982; JASSÓ et al., 1989) szerinti 40 talajtípusból 36-ot, és 86 altípusból 70-et jelenít meg (2. táblázat). 
2. táblázat

A MÉM NAK Genetikus talajtérképen megjelenő talaj altípusok és térkép területhasználati információtartalma

\begin{tabular}{|c|c|c|c|c|}
\hline $\begin{array}{l}(1) \\
\text { Kód }\end{array}$ & $\stackrel{(2)}{\text { Talajaltípus }}$ & $\begin{array}{c}3) \\
\text { Országos } \\
\text { területi } \\
\text { részösszeg, } \\
\text { ha } \\
\end{array}$ & $\begin{array}{c}(4) \\
\text { Országos } \\
\text { területi } \\
\text { részarány, } \\
\% \\
\%\end{array}$ & $\begin{array}{l}\text { (5) } \\
\text { Talajfoltok } \\
\text { száma, db }\end{array}$ \\
\hline \multicolumn{5}{|c|}{ A. Talajkategóriák } \\
\hline 112 & $\begin{array}{l}\text { Nem podzolos agyagbemosódásos } \\
\text { barna erdőtalaj }\end{array}$ & 813756,52 & 8,77 & 533 \\
\hline 201 & Karbonátos réti csernozjom talaj & 660408,26 & 7,12 & 248 \\
\hline 301 & Karbonátos réti talaj & 573247,02 & 6,18 & 579 \\
\hline 51 & Karbonátos humuszos homoktalaj & 509109,92 & 5,49 & 174 \\
\hline 191 & $\begin{array}{l}\text { Típusos meszes vagy mészlepedékes } \\
\text { csernozjom talaj }\end{array}$ & 426291,34 & 4,59 & 135 \\
\hline 131 & Típusos Ramann-féle barna erdőtalaj & 405404,06 & 4,37 & 323 \\
\hline 132 & $\begin{array}{l}\text { Rozsdabarna Ramann-féle barna erdő- } \\
\text { talaj }\end{array}$ & 375295,17 & 4,04 & 214 \\
\hline 312 & Nem karbonátos öntés réti talaj & 330458,38 & 3,56 & 139 \\
\hline 311 & Karbonátos öntés réti talaj & 253726,45 & 2,73 & 179 \\
\hline 391 & Karbonátos humuszos öntés talaj & 251272,50 & 2,71 & 141 \\
\hline 291 & Szolonyeces, szolonyeces réti talaj & 178986,02 & 1,93 & 171 \\
\hline 392 & Nem karbonátos humuszos öntés talaj & 176254,55 & 1,90 & 100 \\
\hline 162 & $\begin{array}{l}\text { Nem karbonátos csernozjom barna } \\
\text { erdőtalaj }\end{array}$ & 156101,00 & 1,68 & 83 \\
\hline 331 & Karbonátos csernozjom réti talaj & 154914,41 & 1,67 & 146 \\
\hline 302 & Nem karbonátos réti talaj & 152543,68 & 1,64 & 137 \\
\hline 171 & $\begin{array}{l}\text { Karbonátos erdőmaradványos csernoz- } \\
\text { jom talaj }\end{array}$ & 151701,06 & 1,63 & 94 \\
\hline 161 & Karbonátos csernozjom barna erdőtalaj & 138923,92 & 1,50 & 116 \\
\hline 205 & Szolonyeces réti csernozjom talaj & 127346,57 & 1,37 & 63 \\
\hline 241 & Kérges réti szolonyec talaj & 126777,05 & 1,37 & 158 \\
\hline 211 & Karbonátos terasz csernozjom talaj & 121779,93 & 1,31 & 59 \\
\hline 141 & Típusos kovárványos barna erdőtalaj & 121027,14 & 1,30 & 36 \\
\hline 395 & Réti humuszos öntés talaj & 107733,58 & 1,16 & 106 \\
\hline 242 & Közepes réti szolonyec talaj & 93194,08 & 1,00 & 156 \\
\hline 52 & Nem Karbonátos humuszos homoktalaj & 84020,89 & 0,91 & 94 \\
\hline 180 & Kilúgzott csernozjom talaj & 76282,64 & 0,82 & 21 \\
\hline 204 & $\begin{array}{l}\text { Mélyben szolonyeces réti csernozjom } \\
\text { talaj }\end{array}$ & 74771,12 & 0,81 & 57 \\
\hline 292 & $\begin{array}{l}\text { Erősen szolonyeces, szolonyeces réti } \\
\text { talaj }\end{array}$ & 73591,30 & 0,79 & 119 \\
\hline 202 & Nem karbonátos réti csernozjom talaj & 73181,04 & 0,79 & 57 \\
\hline 45 & Kovárványos futóhomok talaj & 71610,93 & 0,77 & 18 \\
\hline 321 & Típusos lápos réti talaj & 63549,45 & 0,68 & 72 \\
\hline
\end{tabular}


2. táblázat folytatása

\begin{tabular}{|c|c|c|c|c|}
\hline $\begin{array}{l}\text { (1) } \\
\text { Kód }\end{array}$ & $\begin{array}{c}(2) \\
\text { Talajaltípus }\end{array}$ & $\begin{array}{c}\text { (3) } \\
\text { Országos } \\
\text { területi } \\
\text { részösszeg, } \\
\text { ha }\end{array}$ & $\begin{array}{c}(4) \\
\text { Országos } \\
\text { területi } \\
\text { részarány, } \\
\% \\
\end{array}$ & $\begin{array}{c}\text { (5) } \\
\text { Talajfoltok } \\
\text { száma, db }\end{array}$ \\
\hline 121 & $\begin{array}{l}\text { Podzolos pszeudoglejes barna } \\
\text { erdőtalaj }\end{array}$ & 58096,62 & 0,63 & 38 \\
\hline 231 & $\begin{array}{l}\text { Karbonátos szoloncsák-szolonyec } \\
\text { talaj }\end{array}$ & 57367,48 & 0,62 & 114 \\
\hline 122 & $\begin{array}{l}\text { Agyagbemosódásos pszeudoglejes } \\
\text { barna erdőtalaj }\end{array}$ & 53646,06 & 0,58 & 81 \\
\hline 172 & $\begin{array}{l}\text { Nem karbonátos erdőmaradványos } \\
\text { csernozjom talaj }\end{array}$ & 52177,96 & 0,56 & 28 \\
\hline 402 & Erdőtalaj eredetű lejtőhordalék talaj & 48 806,91 & 0,53 & 86 \\
\hline 350 & Rétláp talaj & 45682,18 & 0,49 & 37 \\
\hline 221 & Karbonátos szoloncsák talaj & 40628,59 & 0,44 & 18 \\
\hline 53 & $\begin{array}{l}\text { Karbonátos több rétegü humuszos } \\
\text { homoktalaj }\end{array}$ & 35346,77 & 0,38 & 22 \\
\hline 243 & Mély réti szolonyec talaj & 34228,61 & 0,37 & 53 \\
\hline 393 & $\begin{array}{l}\text { Karbonátos többrétegü humuszos } \\
\text { öntés talaj }\end{array}$ & 34022,34 & 0,37 & 26 \\
\hline 361 & $\begin{array}{l}\text { Tőzegláp lecsapolt és telkesített rétláp } \\
\text { talaj }\end{array}$ & 32411,41 & 0,35 & 22 \\
\hline 143 & $\begin{array}{l}\text { Agyagbemosódásos kovárványos } \\
\text { barna erdőtalaj }\end{array}$ & 32312,94 & 0,35 & 24 \\
\hline 334 & $\begin{array}{l}\text { Mélyben szolonyeces csernozjom réti } \\
\text { talaj }\end{array}$ & 31504,03 & 0,34 & 49 \\
\hline 41 & Karbonátos futóhomok talaj & 28310,81 & 0,31 & 31 \\
\hline 192 & $\begin{array}{l}\text { Alföldi meszes vagy mészlepedékes } \\
\text { csernozjom talaj }\end{array}$ & 24446,04 & 0,26 & 24 \\
\hline 203 & Mélyben sós réti csernozjom talaj & 23731,62 & 0,26 & 18 \\
\hline 332 & Típusos csernozjom réti talaj & 20371,81 & 0,22 & 26 \\
\hline 303 & Mélyben sós réti talaj & 19086,99 & 0,21 & 14 \\
\hline 364 & $\begin{array}{l}\text { Telkesített rétláp, lecsapolt és telkesí- } \\
\text { tett rétláp talaj }\end{array}$ & 18714,58 & 0,20 & 8 \\
\hline 335 & Szolonyeces csernozjom réti talaj & 17796,51 & 0,19 & 28 \\
\hline 72 & Barna rendzina talaj & 17497,29 & 0,19 & 43 \\
\hline 281 & $\begin{array}{l}\text { Szulfátos vagy kloridos szoloncsákos } \\
\text { réti talaj }\end{array}$ & 15845,00 & 0,17 & 23 \\
\hline 71 & Fekete rendzina talaj & 15256,15 & 0,16 & 17 \\
\hline 304 & Mélyben szolonyeces réti talaj & 12416,77 & 0,13 & 3 \\
\hline 362 & $\begin{array}{l}\text { Tözegesláp lecsapolt és telkesített } \\
\text { rétláp talaj }\end{array}$ & 11943,10 & 0,13 & 13 \\
\hline 10 & Köves, sziklás váztalaj & 11917,10 & 0,13 & 25 \\
\hline 20 & Kavicsos váztalaj & 11837,46 & 0,13 & 10 \\
\hline 282 & Karbonátos szoloncsákos réti talaj & 10734,60 & 0,12 & 23 \\
\hline 394 & $\begin{array}{l}\text { Nem karbonátos többrétegü humuszos } \\
\text { öntés talaj }\end{array}$ & 8960,27 & 0,10 & 7 \\
\hline
\end{tabular}




\begin{tabular}{|c|c|c|c|c|}
\hline \multicolumn{5}{|c|}{ 2. táblázat folytatása } \\
\hline $\begin{array}{l}\text { (1) } \\
\text { Kód }\end{array}$ & $\stackrel{(2)}{\text { Talajaltípus }}$ & $\begin{array}{l}\text { (3) } \\
\text { Országos terüle- } \\
\text { ti részösszeg, ha }\end{array}$ & $\begin{array}{c}\text { (4) } \\
\text { Országos } \\
\text { területi rész- } \\
\text { arány, \% }\end{array}$ & $\begin{array}{l}\text { (5) } \\
\text { Talajfoltok } \\
\text { száma, db }\end{array}$ \\
\hline 333 & $\begin{array}{l}\text { Mélyben sós csernozjom réti } \\
\text { talaj }\end{array}$ & 7512,75 & 0,08 & 9 \\
\hline 251 & $\begin{array}{l}\text { Közepes sztyeppesedő réti } \\
\text { szolonyec talaj }\end{array}$ & 6507,76 & 0,07 & 11 \\
\hline 363 & $\begin{array}{l}\text { Kotusláp lecsapolt és telkesített } \\
\text { rétláp talaj }\end{array}$ & 5335,50 & 0,06 & 8 \\
\hline 31 & Karbonátos földes kopár talaj & 4689,89 & 0,05 & 14 \\
\hline 370 & Mocsári erdőtalaj & 3528,85 & 0,04 & 5 \\
\hline 403 & $\begin{array}{l}\text { Deluviális és aluviális vegyes } \\
\text { üledék, lejtőhordalék talaj }\end{array}$ & 3420,81 & 0,04 & 3 \\
\hline 42 & Nem karbonátos futóhomok $\mathrm{t}$. & 3264,56 & 0,04 & 4 \\
\hline 60 & Humuszkarbonát talaj & 2737,16 & 0,03 & 8 \\
\hline 381 & Karbonátos nyersöntés talaj & 1989,54 & 0,02 & 5 \\
\hline 382 & Nem karbonátos nyersöntés t. & 1951,00 & 0,02 & 2 \\
\hline 232 & $\begin{array}{l}\text { Karbonátszulfátos szoloncsák- } \\
\text { szolonyec talaj }\end{array}$ & 1593,42 & 0,02 & 7 \\
\hline 252 & $\begin{array}{l}\text { Mély sztyeppesedő réti } \\
\text { szolonyec talaj }\end{array}$ & 1245,87 & 0,01 & 1 \\
\hline 43 & $\begin{array}{l}\text { Karbonátos lepelhomok, futó- } \\
\text { homok talaj }\end{array}$ & 998,79 & 0,01 & 4 \\
\hline 32 & $\begin{array}{l}\text { Nem karbonátos földes kopár } \\
\text { talaj }\end{array}$ & 656,90 & 0,01 & 3 \\
\hline $360 *$ & $\begin{array}{l}\text { Lecsapolt és telkesített rétláp } \\
\text { talaj }\end{array}$ & 521,47 & 0,01 & 3 \\
\hline 73 & Vörös agyagos rendzina talaj & 475,15 & 0,01 & 1 \\
\hline $300 *$ & Réti talaj & 463,77 & $<0,01$ & 2 \\
\hline 80 & Fekete nyirok talaj & 441,96 & $<0,01$ & 3 \\
\hline 401 & $\begin{array}{l}\text { Csernozjom eredetü lejtőhorda- } \\
\text { lék talaj }\end{array}$ & 297,39 & $<0,01$ & 3 \\
\hline \multirow[t]{2}{*}{90} & $\begin{array}{l}\text { Erősen savanyú, nem podzolos } \\
\text { barna erdőtalaj }\end{array}$ & 271,40 & $<0,01$ & 2 \\
\hline & a) Összesen & 9278433,75 & 84,10 & 3333 \\
\hline \multicolumn{5}{|c|}{ B. Nem talajkategóriák } \\
\hline & Erdő & 1261180,16 & 13,59 & 1672 \\
\hline & Vízjárta terület & 6463,53 & 0,07 & 1 \\
\hline & Víz & 102864,80 & 1,11 & 131 \\
\hline & Lakott terület & 105109,30 & 1,13 & 77 \\
\hline & a) Összesen & 147617,78 & 15,90 & 1881 \\
\hline
\end{tabular}

Megjegyzés: * Altípus besorolás is megtalálható, de ezeket a foltokat talajtípus szinten kategorizálták. 
A százezer hektárnál nagyobb területen jelölt talaj altípusok száma 22. Ezen belül leggyakoribbnak a nem podzolos agyagbemosódásos barna erdőtalajt mutatja a térkép, míg a réti öntés talaj csak az ország 1,16 százalékát teszi ki. Ez a 22 talaj altípus fedi le az ország területének $68 \%$-át.

A genetikus talajtérkép szerint hazánkban legnagyobb területi kiterjedésben elöforduló három talajaltípus a nem podzolos agyagbemosódásos barna erdőtalaj $(8,77 \%)$, a karbonátos réti csernozjom talaj $(7,12 \%)$ és a karbonátos réti talaj $(6,18 \%)$. A négynél kevesebb foltban előforduló talajtani kategóriák száma 13, ezek közül nyolcnak a területe kisebb, mint ezer hektár, de a 13 együttesen is csak az ország területének $0,27 \%$-át fedi le. Két olyan talajtípus is szerepel a listában, amelyek altípusai is megjelennek a térképen, de ez a néhány folt nem kapott altípus besorolást (típusos réti talaj, lecsapolt és telkesített rétláp talaj).

A földminősítési célú nagy méretarányú talajtérképezési útmutatóban (JASSÓ et al., 1989) rögzített, és miniszteri rendeletben (MÉM, 1981) is elöírt talajosztályozási kategóriák közül 4 talajtípust és 16 altípust nem tartalmaz a térkép. Ez a talajosztályozási rendszer kb. ötöde a kategóriák számát tekintve. A magyarázat vélhetően a térkép méretarányában és a komplex (több kategóriát együttesen tartalmazó) ábrázolás hiányában keresendő.

A hiányzó talajtípusok a következők: podzolos és karbonátmaradványos barna erdőtalaj, szology talaj és mohaláp talaj. A hiányzó talajaltípusok közé sorolandók: nem karbonátos lepelhomok és tereprendezett futóhomok talaj, kovárványos humuszos homoktalaj, podzolos agyagbemosódásos barna erdőtalaj, podzolos és humuszos kovárványos barna erdőtalaj, nem karbonátos terasz csernozjom talaj, karbonátszulfátos és karbonátkloridos szoloncsák talaj, karbonátkloridos szoloncsák-szolonyec talaj, szoloncsákos és szolonyeces másodlagosan elszikesedett talaj, szoloncsákos és szolonyeces lápos réti talaj, karbonátos többrétegü és nem karbonátos többrétegű nyersöntés talaj. A nagyméretarányú talajtérképezéshez készült Útmutatóban (JASSÓ et al., 1989) ismertetett talajrendszertani felosztással ellentétben a talajtérképen a szerkesztők külön ábrázolták a csernozjom réti talaj mélyben sós és mélyben szolonyeces altípusát.

A genetikus üzemi talajtérképezés módszerkönyvben (SzABOLCS et al., 1966) leírt 32 talajképző kőzetből 28-at ábrázoltak a térképen, amelyekböl 21-et tudtunk teljes egyértelmüséggel megfeleltetni az Útmutató (JASSÓ et al., 1989) szerinti besorolásnak. A MÉM NAK talajtérkép külön jelölte a kotus tôzeges és a kotu tőzeg fizikai féleségü talajokat.

Országos összesítésben a szántóterületeken legnagyobb területi kiterjedésben agyag $(15,03 \%)$, öntés iszap $(13,25 \%)$ és homok $(13,05 \%)$ talajképző kőzeten alakultak ki talajféleségek. A térkép továbbá arról szolgáltat információt, hogy döntő mértékben vályog $(22,53 \%)$, agyagos vályog $(17,62 \%)$ és agyag $(15,76 \%)$ fizikai féleségű talajok az uralkodók. Az SRTM modell szerint átlagosan legmagasabb térszínen az erősen savanyú, nem podzolos barna erdőtalajok (323 m), a köves, sziklás váztalajok $(250 \mathrm{~m})$ és a podzolos pszeudoglejes barna erdőtalajok $(246 \mathrm{~m})$ találhatók. Az átlagos legalacsonyabb tengerszint feletti magasságon pedig az erősen szolonyeces réti talajok $(82 \mathrm{~m})$, a mély sztyeppesedő réti szolonyec talajok ( 83 m) és a kérges réti szolonyec talajok ( $84 \mathrm{~m}$ ) helyezkednek el. 
A MÉM NAK talajtérkép és a vele leginkább összevethető AGROTOPO adatbázis összehasonlítására kiválasztottunk két területet. Az egyik az ÉszakMagyarországi-középhegység nagytáj volt, mert itt a legkisebb a talajtani kategóriák száma. A középtájak között viszonylag kicsi a talajtípusok változatossága, ezért lehetőség nyílt a legelterjedtebb talajok előfordulását áttekinteni $(5 \%$ feletti részarány a középtáj területéhez viszonyítva) az egész nagytájon belül. A másik az Észak-alföldi hordalékkúp-síkság középtáj volt, mert itt a legnagyobb a talajtípusok változatossága egyrészt a táj nagysága (a hetedik legnagyobb középtáj), valamint másrészt a talajok tényleges változatossága miatt vizsgáltuk. Az AGROTOPO adatbázis a nagy tavak és Budapest kivételével az egész ország területét lefedi talajtani információkkal, míg a MÉM NAK genetikus talajtérkép az erdők területére nem közöl talajtani adatokat. A jobb összehasonlíthatóság érdekében az AGROTOPO adatbázist szükítettük a MÉM NAK talajtérkép nem talajtani adatainak a területével, így pontosan ugyanakkora terület összehasonlítása vált lehetővé. Ennek az Észak-Magyarországi-középhegység esetében volt nagy jelentősége, mert az a leginkább erdősült nagytájunk.

A magassági adatok részletes statisztikai összehasonlítását elvégeztük. Az átlagos adatokból kiindulva a következő közelítés tehető: az Észak-Magyarországiközéphegység esetében a magassági modell egy foltra eső adatainak (pixel) átlagos száma 33 544, a minimum és maximum értékek pedig: 4750 és 198 907. Az eredeti magasság adatok szórása 20,7 és 106,4 között változik. Az átlagok különbségének a szórása a nagy átlagos elemszámok miatt kicsi, $0,76 \mathrm{~m}$ átlagos szintkülönbség két átlagos kategória között már szignifikáns. Hasonló számítással az Észak-Alföldi hordalékkúp-síkság kategóriái között 0,14 m szintkülönbség már szignifikáns, a szórások alacsonyabb értéke és a hasonló pixel darabszámok miatt.

A 3. táblázat mutatja az Észak-Magyarországi-középhegység középtájainak öszszehasonlítását. A nagyobb, közepes és kis területarányú talajtípusok (5\% felett, $1-$ $5 \%$ és $1 \%$ alatt) foltjainak a száma nagyon közel van egymáshoz az AGROTOPO és a MÉM NAK térképen. Együttes számukat tekintve csaknem pontosan megegyeznek, 72 db középtáj határokkal elválasztott foltban jelennek meg eltérő talajok a MÉM NAK térképen és $73 \mathrm{db}$ foltban az AGROTOPO adatbázisban. A tematikus felbontásban megvan a teljes adatbázisokra jellemzö különbség, a MÉM NAK térkép 27 eltérő kategóriát ábrázol a nagytájon belül, az AGROTOPO pedig 17-et.

Az Északi-középhegység középtájaiban a talajtani kategóriák a Börzsönyben fedik a terület legkisebb részét (28,6\%), a Cserhát, Mátra és az Észak-magyarországi medencék területén ez az arány 76-77\%, a többi tájban pedig $45-53 \%$, tehát jelentős az erdősültség. A leggyakoribb talajtípusok ( $5 \%$ felett) összesített területi részaránya nagyon hasonló a két adatbázisban, a mezőgazdasági terület döntő részén is ezek találhatók.

A rendzinák, a pszeudoglejes barna erdőtalaj és a fiatal, nyers öntéstalajok csak az AGROTOPO adatbázisban szerepelnek a gyakori talajok között. A rozsdabarna erdőtalaj és az erdőmaradványos csernozjom talajok pedig csak a MÉM NAK térképen jelennek meg. A rozsdabarna erdőtalaj jelölésének hiányára magyarázat, hogy az AGROTOPO nem tesz különbséget a barnaföldek között, tehát az magában 
foglalja rozsdabarna erdőtalajt is. Az egyéb különbségek is az osztályozás eltéréséből adódnak.

A MÉM NAK térkép karbonátos humuszos öntés talaját és az AGROTOPO réti öntés talaját egy oszlopban tüntettük fel genetikai hasonlóságuk miatt. Az öntéstalajok a MÉM NAK térképen négy középtájban gyakoriak, az AGROTOPO adatbázis alapján a négy közül háromban. Az átlagos magassági adatok szélső értékei 109163 m és 103-157 m, tehát az osztályozás különbségei ellenére jó korrelációt látunk. A csernozjom barna erdőtalajok az AGRROTOPO adatbázis alapján öt középtájban gyakoriak, a MÉM NAK térképen ebből az ötből háromban. Az átlagos magasság nagyon szük tartományban van az AGROTOPO adatbázisban (155-159 m), és kicsit tágabb a másik térkép alapján (141-178 m) tehát a magassági tartományok átfednek.

A barnaföldeket hét középtájban jelöli az AGROTOPO és ezeken belül öt középtájban a MÉM NAK térkép. Az átlagos magassági tartományok 165-209 és 186-235 m, tehát az AGROTOPO kicsivel magasabban előfordulónak mutatja ezt a talajtípust. A leggyakoribb talajtípus az agyagbemosódásos barna erdőtalaj, amely mindkét térképen minden középtájban gyakori, és ez van legmagasabban: 198-256 m és 216-270 m, tehát ebben az esetben is az AGROTOPO szerint kicsivel magasabban van ez a talajtípus.

STEFANOVITS (1963) a középtáj talajinak jellemzését elsősorban a kialakulásukra ható geológiai folyamatok és tényezök alapján tárgyalja. A szerző csak a Mátra esetében ismerteti a talajok tengerszintfeletti magasság mentén való elhelyezkedését. A szerző leírása szerint a Mátrában 150 és 1000 m közötti szintkülönbségen a klimatikus zonalitásnak megfelelően legalul, a hegylábi területeken a csernozjom és a Ramann-féle barna erdőtalajok egymással váltakozva helyezkednek el. A tengerszint feletti magasság emelkedésével az utóbbiakat felváltják az agyagbemosódásos barna erdőtalajok, amelyek kis mértékben podzolosodhatnak. A hegység gerincein erősen savanyú, nem podzolos erdőtalajok alakultak ki. A legmagasabb térszíneken, a szélnek kitett gerinceken vagy az erodált meredek lejtőkön erubáz (fekete nyirok) talajok fordulnak elö.

A két térkép elemzésével kapott eredmény nem mutatja a mozaikos barnaföld és csernozjom barna erdőtalaj előfordulást, továbbá határozott magassági elkülönülést találunk. Az agyagbemosódásos barna erdőtalaj magasabb térszíni megjelenése egybecseng az irodalmi forrással. A még magasabban fekvő talajok összehasonlítására jelen elemzésünkben nincs lehetőség, mert azok már erdővel fedett területen vannak.

Az 4. táblázatban mutatjuk be az Észak-alföldi hordalékkúp-síkság 1\%-nál nagyobb területen megtalálható kategóriáit a két adatbázis alapján. Az adatbázisok tematikus különbségei itt még inkább kiütköznek. Az AGROTOPO 18 db kategóriájával szemben a MÉM NAK térképen 39 db eltérő kategóriát találunk, ami a rajzolat nagyobb részletességét is eredményezi. A két adatbázis talajtípusait ebben az esetben is próbáltuk a lehető legjobban megfeleltetni egymásnak. Az AGROTOPO adatbázis kovárványos barna erdőtalaj és barnaföld kategóriáinak nem volt még hozzávetőleges megfelelöje sem, a többi esetben az azonos, vagy hasonló kategóriákat egy sorba írtuk. 
Az AGROTOPO adatbázis réti csernozjom talaját összevontan szerepeltetjük a 4. táblázatban a mélyben sós és mélyben szolonyeces altípusaival, továbbá az alföldi mészlepedékes csernozjom kategóriába összevontan szerepeltetünk minden olyan talajtípust és altípust, amelyek egyébként igen kis területüek, valamint a meszes és a mészlepedékes csernozjomok közé sorolhatók (190 kód). A MÉM NAK térkép 19 $\mathrm{db}$ feltüntetett altípusának 10 esetben volt megfelelöje az AGROTOPO adatbázisban. Az elemzésünkben ezekre szorítkoztunk.

Legmélyebb térszínen a szolonyecek találhatók (88-91 m), melyek mély altípusa vagy sztyeppesedő típusa kicsivel magasabban van (91-92 m). Ezek a talajtípusok jóval gyakoribbak az AGROTOPO adatbázis adatai szerint. A szolonyeces réti talajok 92-93 m átlagos magasságban helyezkednek el, és szintén az AGROTOPO szerint vannak nagyobb területen. A réti csernozjomok átlagos magassága 98-99 m és a gyakoriságuk is csak kismértékben eltérő a két adatbázisban. A réti talajok átlagos magassága 100-101 m, de az AGROTOPO sokkal elterjedtebbnek mutatja. A karbonátos réti csernozjom talajokat (MÉM NAK) és az alföldi mészlepedékes csernozjom talajokat (AGROTOPO) egy sorban tüntettük fel részleges hasonlóságuk miatt, de az átlagos magassági adatok erős eltérése (108 és $101 \mathrm{~m}$ ), valamint az AGROTOPO adatbázisban való sokkal nagyobb területi részaránya is a két kategória eltérésére utal.

A futóhomok talajok viszonylag kis területen vannak, de az AGROTOPO alapján magasabb térszínen találhatók (110 és $135 \mathrm{~m}$ ). A humuszos homoktalajok átlagos magassága gyakorlatilag megegyezik az adatbázisokban $(110-111 \mathrm{~m})$, de a MÉM NAK térkép jóval gyakoribbnak mutatja ezt a talajtípust. Egy sorban tüntettük föl a karbonátos humuszos öntéstalajt (MÉM NAK, $114 \mathrm{~m}$ ) és a réti öntés talajt (AGROTOPO, $108 \mathrm{~m}$ ). A hasonló területi részarány és a kevéssé eltérő magasság adatok hasonló koncepcióra utalnak. A csernozjom barna erdőtalajok az AGROTOPO adatbázisban jóval elterjedtebbek, de gyakorlatilag azonos magasságban vannak a két adatbázisban (127-129 m). Megállapítható, hogy a két adatbázis jól korrelál, és az AGROTOPO nagyobb területi elterjedést mutató adatai a kisebb tematikus részletességgel függnek össze.

VÁRALLYAY és munkatársai (1980) közleménye erre a középtájra hárommal több talajtípust jelöl, mint amit mi az AGROTOPO adatbázis alapján kimutattunk. Ennek a magyarázata a területmérés eltérőségében keresendő. Erre igazolást jelent az is, hogy a térinformatikai programmal kimutatott összes terület mintegy 3995 $\mathrm{km}^{2}$, míg az említett publikációban szereplő terület $4304 \mathrm{~km}^{2}$.

STEFANOVITS (1963) talajtáj beosztásában két táj (Jászság és a KözépTiszavidék) északi része esik egybe a jelenlegi természeti földrajzi tájbeosztásban az Észak-alföldi hordalékkúp-síkság középtájjal. A szerző szerint ezen a területen az Északi-középhegységhez közel eső, magasabban fekvő hegylábi területeken andezittel kevert lejtőlösz talajképző kőzeten főként csernozjom barna erdőtalajok találhatók. A néhány méterrel alacsonyabban fekvő térszínen agyagos löszszerü hordalékon és gyakran a felszínre bukkanó fekete réti agyagon réti és szikes talajféleségek vannak. A Jászságban humuszos homoktalajokat is leír a szerzö, és a humuszos kovárványos talajokat, mint a táj jellegzetességét említi. 
TÓTH és munkatársai (2001) közleménye szerint az Észak-alföldi hordalékkúpsíkság középtájban a szikesek részaránya kistájanként erősen változó, néhol hiányoznak, egy kistájban pedig 50\% fölötti a részarányuk. Meg kell azonban jegyezni, hogy a szerzők SZABOLCS (1974) munkáját vették alapul a szikesek lehatárolásánál. Vizsgálataik szerint a szikesek $70 \%$-a agyag talajképző kőzeten alakul ki. Kőzetlisztes talajképző kőzet esetén a szulfátos talajvíz sokkal jobban kedvez a szikesek kialakulásának, mint a hidrokarbonátos. Az utóbbi csoportba tartoznak az általunk a vizsgált középtáj szikesei is, de a ritkább, hidrokarbonátos változatba (То́тн, 2002). Homok talajképző kőzeten, a kis területen előforduló szikesedést is inkább a szulfátos talajvíz váltja ki.

Az általunk összehasonlított két térképi adatbázis alapján az AGROTOPO jelez nagyobb szikes arányt (mintegy 25\%), a MÉM NAK genetikus talajtérkép csak kb. 17\%-ot, mindkettő elmarad azonban TóTH és munkatársai (2001) munkájában jelzett területarányoktól. A talajtípusok és altípusok magasság szerinti eloszlása követi azt a mintázatot, amit STEFANOVITS (1963) munkájában olvashatunk.

TóTH (2002) egy koncepcionális modellt dolgozott ki, amely szerint egy tipikus szikes talajsorozat a magasság szerint a következö: réti talajok - padkás szolonyecek - szolonyecek - csernozjomok. Ennek a mi eredményeink sem mondanak ellent, de figyelembe kell venni, hogy egy csaknem $4000 \mathrm{~km}^{2}$-es középtájban nagyon nagy szintkülönbségek vannak még alföldi körülmények között is, és ezen belül nagyon sok talajkaténa található.

SISÁK és munkatársai (2015) a határvonalak elemzésére épülő munkájukban szintén bebizonyították a réti talajok, szikesek és csernozjomok szoros asszociációját az Alföldön.

\section{Következtetések}

SISÁK és BENŐ (2014) egy kisebb mintaterületen végzett vizsgálatban megállapították, hogy az országosan egységes térképpé szerkesztett talajtérképek mindegyike, így az itt bemutatott MÉM NAK genetikus talajtérkép is információtöbbletet hordoz a többi térképhez képest.

Jelen tanulmányunkban megmutattuk, hogy azok közül a talajtérképek közül, amelyek a jelenlegi talajosztályozás szerint ábrázolják a talajokat, a MÉM NAK genetikus talajtérkép kitünik abban, hogy a talajosztályozási kategóriák legteljesebb térképi reprezentációját adja.

A részletesebben vizsgált tájak alapján a gyakoribb talajtípusok esetében egyértelmü megfeleltetés tehető a MÉM NAK talajtérkép és az AGROTOPO adatbázis között. A példaként tárgyalt magassági zonalitás részletesebb elemzésére további publikációkban szeretnénk sort keríteni.

A jelenkori magyar talajtan egyik feladata, hogy a múltban nagy munka és költségráfordítással létrehozott talajtérképek és talajadatbázisok mindegyikét digitális formában megmentse az utókor számára, és felhasználja azok információ tartalmát a digitális talajtérképezési munkák során. Ehhez a folyamathoz kívántunk hozzájárulni jelen munkánkkal. 


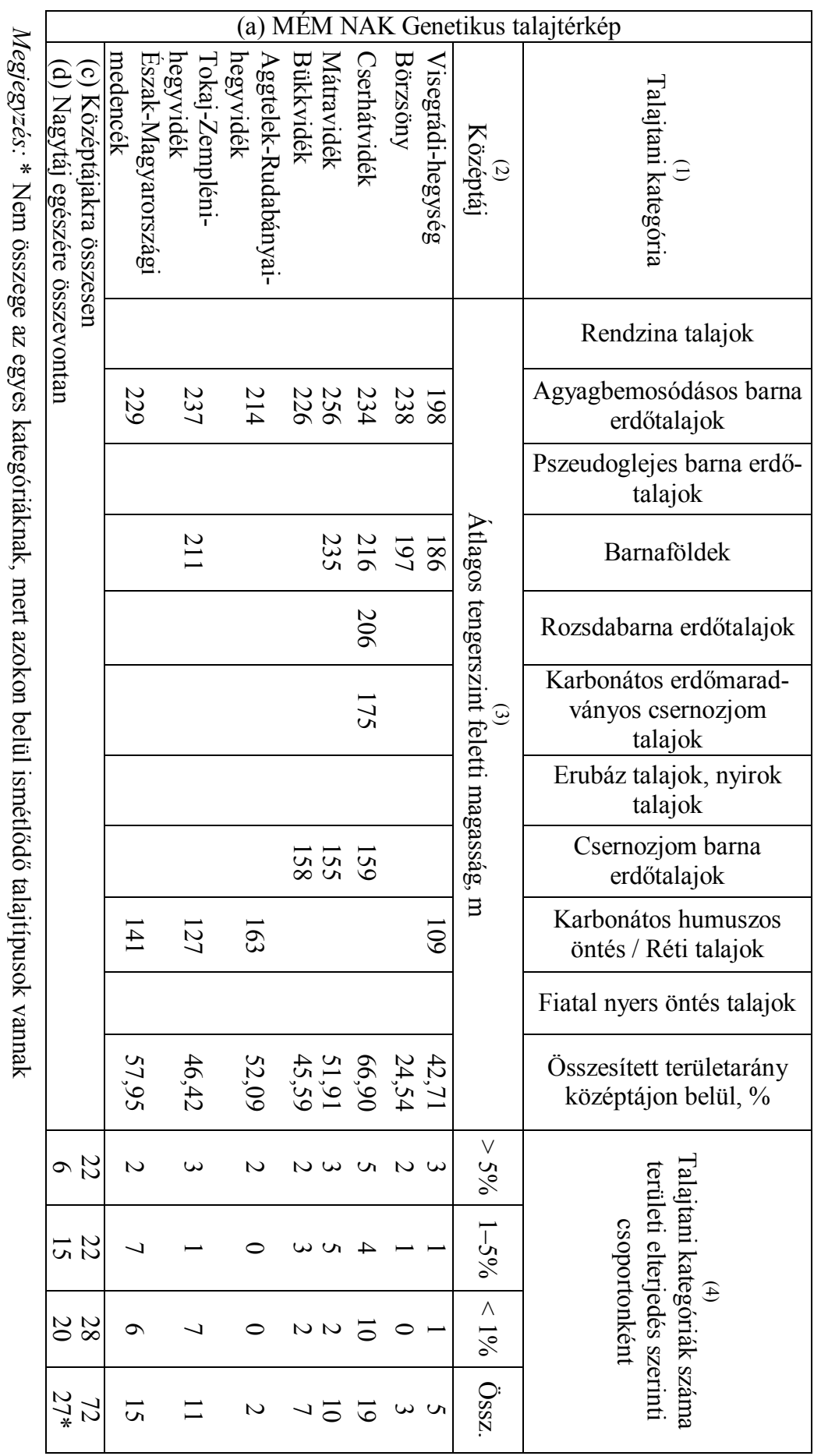




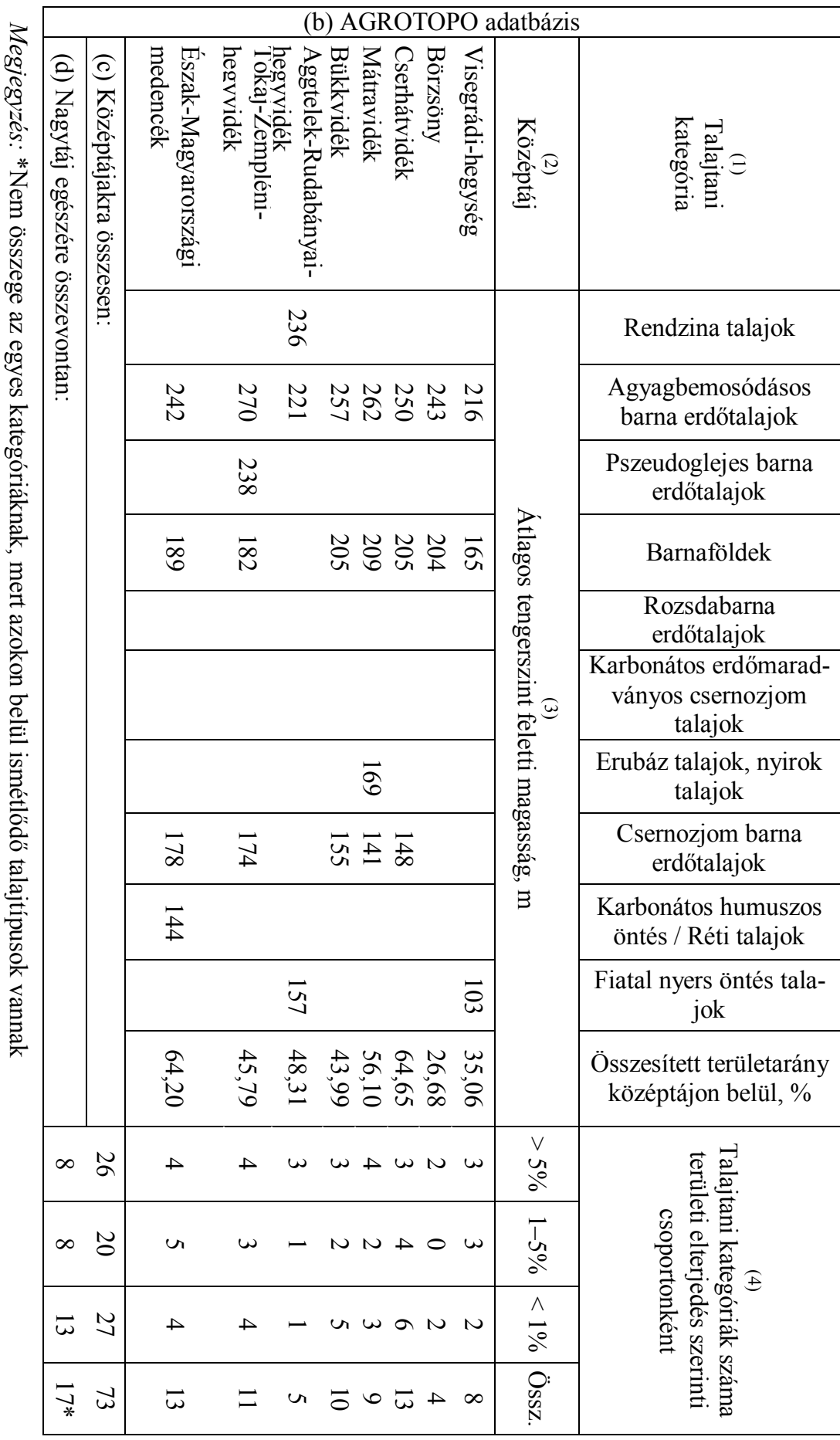


4. táblázat

Az Észak-alföldi hordalék-kúpsíkság talajtípusainak összehasonlítása két talajtérkép alapján

\begin{tabular}{|c|c|c|c|c|}
\hline \multirow{2}{*}{ Talajaltípus / Talajkategóriák } & \multirow{2}{*}{$\begin{array}{c}(2) \\
\text { Területi } \\
\text { arány, \% }\end{array}$} & \multicolumn{3}{|c|}{$\begin{array}{c}(3) \\
\text { Tengerszintfeletti magasság, m }\end{array}$} \\
\hline & & $\begin{array}{l}(4) \\
\text { Min. }\end{array}$ & $\begin{array}{l}(5) \\
\text { Max. }\end{array}$ & Átlag \\
\hline \multicolumn{5}{|c|}{ A. MÉM NAK Genetikus talajtérkép } \\
\hline Közepesen mély réti szolonyec talaj & 1,90 & 83 & 95 & 88,17 \\
\hline Karbonátos csernozjom réti talaj & 3,35 & 81 & 106 & 88,86 \\
\hline Mély réti szolonyec talaj & 1,59 & 78 & 104 & 90,94 \\
\hline Karbonátos szoloncsák-szolonyec talaj & 1,20 & 84 & 109 & 92,14 \\
\hline Mélyben sós réti csernozjom talaj & 1,09 & 83 & 103 & 92,25 \\
\hline Szolonyeces réti talaj & 5,07 & 80 & 123 & 92,37 \\
\hline Karbonátos szoloncsákos réti talaj & 1,63 & 82 & 110 & 92,51 \\
\hline Nem karbonátos réti talaj & 7,80 & 83 & 119 & 97,03 \\
\hline Karbonátos szoloncsák talaj & 4,37 & 87 & 133 & 99,11 \\
\hline Nem karbonátos réti csernozjom talaj & 9,98 & 80 & 162 & 99,47 \\
\hline Karbonátos réti talaj & 1,77 & 80 & 148 & 99,68 \\
\hline Nem karbonátos öntés réti talaj & 20,47 & 80 & 170 & 100,52 \\
\hline Karbonátos réti csernozjom talaj & 2,98 & 95 & 153 & 108,29 \\
\hline Karbonátos futóhomok talaj & 1,49 & 95 & 134 & 110,14 \\
\hline Karbonátos humuszos homoktalaj & 3,20 & 93 & 158 & 111,09 \\
\hline Nem karbonátos humuszos homoktalaj & 6,39 & 87 & 193 & 111,27 \\
\hline Karbonátos humuszos öntés talaj & 4,92 & 92 & 236 & 114,17 \\
\hline Nem karb. csernozjom barnaerdőtalaj & 6,13 & 100 & 206 & 128,53 \\
\hline Nem karb. erdőmaradványos csernozjom t. & 5,33 & 95 & 261 & 139,44 \\
\hline 19 gyakori talajtípus & 90,66 & & & \\
\hline További 20 talajtípus & 7,78 & & & \\
\hline Nem talajkategóriák & 1,56 & & & \\
\hline \multicolumn{5}{|c|}{ B. AGROTOPO adatbázis } \\
\hline Réti szolonyecek & 7,47 & 80 & 122 & 90,51 \\
\hline Sztyeppesedő réti szolonyecek & 3,48 & 80 & 109 & 91,89 \\
\hline Szolonyeces réti talajok & 11,10 & 78 & 127 & 93,19 \\
\hline Réti csernozjomok* & 12,31 & 81 & 130 & 98,31 \\
\hline Réti talajok & 16,60 & 81 & 169 & 101,46 \\
\hline Réti szolonyecek & 7,47 & 80 & 122 & 90,51 \\
\hline Alföldi mészlepedékes csernozjomok* & 12,32 & 80 & 156 & 101,42 \\
\hline Futóhomok & 1,09 & 98 & 220 & 135,25 \\
\hline Kovárványos barna erdőtalajok & 3,02 & 91 & 191 & 106,53 \\
\hline Humuszos homoktalajok & 4,06 & 92 & 179 & 110,23 \\
\hline Réti öntéstalajok & 6,77 & 82 & 171 & 108,33 \\
\hline Csernozjom barna erdőtalajok & 17,03 & 92 & 261 & 127,49 \\
\hline Barnaföldek & 2,67 & 97 & 232 & 137,91 \\
\hline 12 gyakori talajtípus & 97,92 & & & \\
\hline További 1 talajtípus & 0,52 & & & \\
\hline Nem talajkategóriák & 1,56 & & & \\
\hline
\end{tabular}

Megjegyzés: * Összevont kategóriák (magyarázatot lásd a szövegben). 


\section{Összefoglalás}

Tanulmányunkban a Nemzeti Élelmiszerlánc-biztonsági Hivatal (NÉBIH) egyik jogelődje, a Mezőgazdasági és Élelmezésügyi Minisztérium Növényvédelmi és Agrokémiai Központ (MÉM NAK) által készített genetikus talajtérkép digitális állományát mutatjuk be. Az 1983-ban elkészült MÉM NAK talajtérkép az egyetlen olyan országos (1:200.000 méretarányú) kartográfiai munka, amely a jelenleg érvényes talajosztályozási rendszerünkből mind a 9 talaj fötípust, a 40 talajtípusból 36ot, és a 86 altípusból 70-et jelenít meg, továbbá információval szolgál 28 különféle talajképző kőzetről és 9 fizikai féleségéről is.

A vektoros térinformatikai állomány első verziója a 2000-es évek végén, a Növény- és Talajvédelmi Központi Szolgálat koordinálásával készült el. A Genetikus talajtérkép javításával jött létre a dolgozatban bemutatott állomány, amelyet kiválasztott területeken a földrajzi tájbeosztás középtájai és az SRTM modell magasság adatai segítségével értékeltünk és az Agrotopográfiai (AGROTOPO) Adatbázis vektoros állományának talajinformációival hasonlítottuk össze. A genetikus talajtérkép az országos talajtérképek evolúciójának fontos állomása. STEFANOVITS és SzÜCS térképét tekinthetjük a jelenkori talajosztályozás szerinti talajtérképezés első kartográfiai összegzésének, az AGROTOPO ezt adat tartalmában és a rajzolat részletességében továbbfejlesztette, majd a MÉM NAK talajtérkép a talajosztályozási egységek ábrázolása tekintetében jelentett előrelépést. A MÉM NAK genetikus talajtérkép alapot nyújthat koncepcionális talajtérképek elkészítéséhez és minden olyan munkához, amelyben a talajosztályozási kategóriákat érintő tematikus részletessége elönyt jelent.

Kulcsszavak: genetikus talajtérkép, MÉM NAK, középtájak, talajosztályozás

A kutatás a TÁMOP-4.2.2.A-11/1/KONV-2012-0064 projekt keretében készült. Kocsis Mihály publikációt megalapozó kutatása a TÁMOP-4.2.4.A/2-11/1-20120001 azonosító számú Nemzeti Kiválóság Program - Hazai hallgatói, illetve kutatói személyi támogatást biztosító rendszer kidolgozása és müködtetése konvergencia program címü kiemelt projekt keretében zajlott. A projekt az Európai Unió támogatásával, az Európai Szociális Alap társfinanszírozásával valósul meg.

\section{Irodalom}

DombóváRiné FeKete K. \& Stefanovits P., 1996. Mivel gazdagította ismereteinket az ország talaj-agyagásvány térképe? 45. 221-228.

DövÉNYI Z. (szerk.), 2010. Magyarország kistájainak katesztere. Második, átdolgozott és bővített kiadás. MTA Földrajztudományi Kutatóintézet. Budapest.

EC, 2007. Directive 2007/2/EC of the European Parliment and of the Council of 14 March 2007. Establishing an Infrastructure for Spatial Information in the European Community (INSPIRE). 
GÉCZY G., 1959. A gyakorlati talajtérképezés. Új rendszerű talajismereti és talajhasznosítási térkép ismertetése és gyakorlati használhatósága. Doktori értekezés. Gödöllői Agrártudományi Egyetem, Mezőgazdaságtudományi Kar.

GÉCZY G., 1960. Újabb mezőgazdasági talajhasznosítási osztályozási rendszer. Agrokémia és Talajtan 9. 405-418.

GÉCZY G., 1962. Magyarországi talajok osztályozási rendszere és térképezése hasznosíthatóságuk alapján. MTA Agrárgazdálkodási Kutató Intézet 29. sz. kiadványa. Budapest.

GÉCZY G., 1964. Mutatószám a magyarországi talajok természetes termékenysége alapján történő minősítésre Agrokémia és Talajtan. 13. 325-344.

GÉCZY G., 1968. Magyarország mezőgazdasági területe. Akadémiai Kiadó. Budapest.

JASSÓ F. et al., 1989. '88 útmutató a nagyméretarányú országos talajtérképezés végrehajtásához. Agroinform Kiadó. Budapest.

JENEY I. \& JASSÓ F. (Szerk.), 1983. Magyarország genetikus talajtérképe (méretarány: 1:200.000). Kartográfiai Vállalat. Budapest.

Kocsis M., Tóth G., BerénYi Üveges J. \& MAKó A., 2014b. Az Agrokémiai Irányítási és Információs Rendszer (AIIR) adatbázis talajtani adatainak bemutatása és térbeli reprezentativitás-vizsgálata. Agrokémia és Talajtan. 63. (2) 223-248.

Kreybig L., 1937. A Magyar Királyi Földtani Intézet talajfelvételi vizsgálati és térképezési módszere. Budapest.

LÁNG I., CSETE L. \& HARNOS Zs. (szerk.), 1983. A magyar mezőgazdaság agroökológiai potenciálja az ezredfordulón. Mezőgazdasági Kiadó. Budapest.

MAROSI S. \& SOMOGYI S., 1990. Magyarország kistájainak katasztere II. MTA Földrajztudományi Kutatóintézet. Budapest.

MÉM (MEZÖGAZDASÁGI ÉS ÉLELMEZÉSÜGYI MINISZTÉRIUM), 1981. 5/1981 (IV. 2.) MÉM számú rendelet a földértékelési szabályzat kiadásáról. MÉM, Budapest.

MÉM (MEZŐGAZDASÁGI ÉS ÉLELMEZÉSÜGYI MINISZTÉRIUM), 1982. Táblázatok a földértékelés végrehajtásához. MÉM, Budapest.

MÉM (MEZÖGAZDASÁGI ÉS ÉLELMEZÉSÜGYI MINISZTÉRIUM), 1983-1988. Magyar Népköztársaság, Agrotopográfiai térkép 1:100 000. MÉM Országos Földügyi és Térképészeti Hivatal, Budapest. 84. térképlap.

MTA ATK TAKI, 2013. (http://mta-taki.hu/osztalyok/gis-labor/agrotopo)

NÉMeth T., Stefanovits P. \& VÁrallyay Gy., 2005. Talajvédelem. Országos Talajvédelmi Stratégia tudományos háttere. Kármentesítési tájékoztató. Környezetvédelmi és Vízügyi Minisztérium. Budapest.

SISÁK I. \& BÁMER B. 2008. Hozzászólás Szabó, Pásztor és Bakacsi „Egy országos, átnézetes, térbeli talajinformációs rendszer kiépítésének igénye, lehetőségei és lépései” címü cikkéhez. Agrokémia és Talajtan. 57. (2) 347-354.

SISÁK I. \& BENÖ A., 2012. Az AGROTOPO talaj-adatbázis problémái és egy részletesebb talajtérkép előállításának célja, lehetőségei és lépései. In.: Agrárinformatika 2012 Konferencia: Innovatív információtechnológiák az agrárgazdaságban. Konferencia kiadvány. (Szerk: HERDON M. \& SZILÁGYI R.) 44-51. (http://nodes.agr.unideb.hu/ai2012/ dokumentum/ai2012.pdf)

SISÁK I. et al., 2015. Method development to extract spatial association structure from soil polygon maps. Hungarian Geographical Bulletin. 64. (1) 65-78.

StefANOVITS P., 1963. Magyarország talajai. Akadémiai Kiadó. Budapest.

STEFANOVITS P. \& SzÜCS L., 1961. Magyarország genetikus talajtérképe. Országos Mezőgazdasági Minőségvizsgáló Intézet (OMMI) kiadványa. Budapest.

StefANOVITS P., 1989. Map of clay mineral associations in Hungarian soils. 38. 790-799. 
STEFANOVits P. \& DombÓvÁRINÉ FEKETE K, 1985. A talajok agyagásvány-társulásának térképe. 34. 317-330.

SzABOlCS I. (szerk.), 1966. A genetikus üzemi talajtérképezés módszerkönyve. Országos Mezőgazdasági Minőségvizsgáló Intézet (OMMI). Budapest.

SzABOlCS I., 1974: Salt-affected soils in Europe. Martinus Nijhoff, The Hague. The Netherlands.

SZABÓNÉ KELE G., 1999. A termőhelyi értékszám meghatározásának helyzete és a talajtérképes módszer országos befejezésének feltételei. In: A talajminőségre épített EUkonform földértékelés elvi alapjai és bevezetésének gyakorlati lehetősége. (Szerk.: Stefanovits P. \& MichÉli E.) 81-99. Agroinform Kiadó. Budapest

TimÁr G., Telbisz T. \& SzÉKELy B., 2003. Ürtechnológiai a digitális domborzati modellezésben: az SRTM adatbázis. Geodézia és Kartográfia. 55. (12) 11-15.

То́тн T., 2002. Szikes talajok tér- és időbeli változatossága. MTA doktori értekezés tézisei, Budapest.

TóTH G. \& MÁTÉ F., 2006. Megjegyzések egy országos, átnézetes, térbeli talajinformációs rendszer kiépítéséhez. Agrokémia és Talajtan. 55. 473-478.

Tóтн T., Kuti L., Kabos S. \& Pásztor L., 2001. Az alföldi szikes talajok elterjedését meghatározó agrogeológiai tényezők térinformatika elemzése 1:500 000 méretarányban. Földrajzi Konferencia, Szeged 2001. (http://geography.hu/mfk2001/cikkek/ TothKutiKabosPasztor.pdf)

VÁRALlyay Gy. et al., 1979. Magyarország termőhelyi adottságait meghatározó talajtani tényezők 1:100.000 méretarányú térképe I. Agrokémia és Talajtan. 28. 363-384.

VÁRALlyAy Gy. et al., 1980. Magyarország termőhelyi adottságait meghatározó talajtani tényezők 1:100.000 méretarányú térképe II. Agrokémia és Talajtan. 29. 35-76.

VÁRALLYAY GY., 1989. Mapping of hydrophysical properties and moisture regime of soils. Agrokémia és Talajtan 38. 800-817.

VÁrallyay Gy., 2012. Talajtérképezés, talajtani adatbázisok. Agrokémia és Talajtan. 61. (Supplementum) 249-263. (http://www.aton.hu/documents/10156/c4e78c6b-a2bf4441-b367-39e2275d83ce)

Érkezett: 2015. február 12. 


\title{
The genetic soil map of Hungary and the evaluation of the soil categories
}

\author{
${ }^{1}$ M. KoCSIS, ${ }^{2}$ J. BERÉNYI ÜVEGES, G. VÁRSZEGI and ${ }^{1}$ I. SisÁK \\ ${ }^{1}$ Department of Plant Production and Soil Science, Georgikon Faculty, University of Pannonia, \\ Keszthely and ${ }^{2}$ Soil Conservation Regulatory Department; ${ }^{3}$ Department of Agri-environment and \\ Coordination, Directorate of Plant Protection, Soil Conservation and Agri-environment, National \\ Food Chain Safety Office, Budapest (Hungary)
}

\begin{abstract}
Summary
This study presents the digital version of the genetic soil map produced by MÉM NAK the predecessor of the National Food Chain Safety Office (Hungarian acronym: NÉBIH). The 1:200,000 scale printed map was released in 1983 and it is the most complete nationwide representation of the Hungarian soil classification system, comprising all the 9 major soil groups, 36 of the 40 soil types, 70 of the 86 subtypes and giving information on 28 parent materials and 9 texture classes. The compilation of the first version of the polygon map was coordinated by the MÉM-NAK in the late 2000s. The first version was corrected and evaluated in the present work with the help of the SRTM elevation data for two selected areas, and the results were compared with the AGROTOPO soil database. It was concluded that the MÉM NAK genetic soil map was an important stage in the development of nationwide soil maps for Hungary. The map produced by STEFANOVITS and SzÜCS was the first nationwide soil map that used the present soil classification. The next stage was the AGROTOPO map, which had a more detailed soil pattern and a larger database. The added advantage of the MÉM NAK genetic soil map was that it contained much more information on soil types and subtypes. The resulting digital soil map may be of help in producing nationwide conceptual soil maps, where its detailed treatment of soil classification categories could be an advantage.

Table 1. Major soil groups in the MÉM NAK genetic soil map and their area percentage. (1) Code. (2) Main type. (3) Hungarian of genetic soil map. (5) AGROTOPO Database. (6) MÉM NAK genetic soil map. (7) Percent area, \%.

Table 2. Soil sub-types and land use categories in the MÉM NAK genetic soil map. (1) Code. (2) Soil subtype. (3) Country of share sum area (ha). (4) Country of share percent area, \%. (5) Soil patches of number, piece. A. Soil categories; B. Non soil categories. Remark: *Subtypes exist but these patches are categorized at soil type level.

Table 3. Comparison of the soils in the North Hungarian hills based on two databases. (1) Soil categories. (2) Mid-scale landscape unit. (3) Elevation above sea level. (4) Number of soil categories in the surface percentage groups. (a) MÉM NAK Genetic soil map. (b) AGROTOPO soil database. (c) Sum of the midscale landscape units. (d) Total for the main landscape unit. Remark: *Not sum of the numbers to the left because of the repeated soil categories.

Table 4. Comparison of the soils in the North-Great-Plain fan based on two databases. A. MÉM NAK Genetic soil map. B. AGROTOPO soil database. (1) Soil types / Soil categories. (2) Area percentage. (3) Elevation above sea level, m. (4) Min. (5) Max. (6) Mean. Remark: *Compound categories (see explanation in the text).
\end{abstract}

